\title{
Management and Assessment of Human Performance Toward Service Quality: The Case of Kosovo's Public Sector
}

\author{
Submitted 14/04/19, 1st revision 25/05/19, 2nd revision 15/06/19, accepted 30/07/19
}

\author{
Ibrahim Krasniqi ${ }^{1}$, Bedri Statovci ${ }^{2}$
}

\begin{abstract}
:
Purpose: The article focuses in the management and assessment of human performance in the public sector in the state of Kosovo as a key factor for sustainable development and quality increase in the local governance level. Usually management of performance measurement in local governance was concentrated in result delivery without talking into consideration the key factors for effective work such as performance measurement indicators. Nowadays this correlation between performance measurement management and quality increase of services is becoming very important. The article aims to consider and support the fact that the linkage of local government performance assessment is strongly affecting the service quality toward consumers and citizens.

Design/Methodology/Approach: For the purpose of this study we have covered a broad literature review followed by primary data collection through questionnaires and semistructured interviews with key experts, relevant reports and other related documentation.

Findings: The paper found that there is dissatisfaction among stakeholders with actual way and framework for management of performance measurement and highlights the necessary changes and advancement toward an improved framework for modern performance measurement in order to increase the service quality and satisfy the needs of businesses, consumers and citizens, while indirectly supports the motivation in the workplace.

Practical Implications: The paper will serve as a guide for public sector management and aims to facilitate the motivation among employees. This will lead to increase of efficiency and indirectly will support the overall satisfaction among costumers, citizens and businesses. Originality/Value: The research aims to establish valuable performance management systems and develop a model that will serve as one tool for motivation, service quality and efficiency increase between public sector and public management.
\end{abstract}

Keywords: Management, motivation, human performance assessment, service quality, public sector management.

JEL code: $M 12, H 11, H 70, H 83$.

Paper type : Research article.

\footnotetext{
${ }^{1}$ University Haxhi Zeka, Faculty of Business, Peja; ibrahim.krasniqi@unhz.eu

${ }^{2}$ Corresponding author, University Haxhi Zeka, Faculty of Business, Peje,

Bedri.Statovci@unhz.eu
} 


\section{Introduction}

Management of local governance in general has passed through different development stages and obstacles toward the increase of efficiency and satisfaction of their "clients", citizens and businesses (Brignall, 2000). Actually, the "value for money" approach (Palmer, 1993) is becoming an important indicator for local government management and quality increase of services provided (World Economic Forum, 2013). Employee's performance in local government institutions is important to improve service quality not only for the institutions but also for them. There is evidence of correlation showing that high performance implies to the productivity increase of the organization (Christensen et al., 2007).

Focusing in modern approach toward performance assessment it will be a motivating factor for employees and in this regard, performance comprehensively involves the individual's behavior and outcome, making the employee to fulfill his/her duties (Sonnentag and Frese, 2002). However, with the expectations going up for quality services at all levels it increases accountability, effectivity and efficiency. This highlighted the importance of modern performance assessment (Hood, 1995). Traditionally assessment of performance has mostly been supported through the indicator of development based on inputs and costs. However this approach was criticized because of the total absence of non-financial dimensions during the assessment of performance and management (Atkinson et al., 1997). With the time, performance assessment and evaluation have become important factors that enable and motivate employees to improve service quality. Therefore, the research question is how management of performance assessment systems can increase the service quality level in local government in Kosovo (Krasniqi et al., 2015).

\section{Literature Review}

Nowadays due to globalization and global competiveness for the qualified workforce the human performance management is becoming a key factor for the overall work quality and efficiency. Much more contribution has been done toward performance measurement systems and explanations of these, but not as much efforts are widely used in the comprehensive performance management approach and the link of these important variables specifically not in public sector organizations. Over the past decades the debate about the roles and responsibilities from local governance level has reflected toward a broader concept of performance management including nonfinancial means (Walker et al., 2010). However, this debate is mostly concentrated in economic reasons comparing this with responsiveness and approach toward citizens and businesses (Afull-Broni, 2012). After 1990 with global changes the pressure for better and faster services have increased the reaction in many governments and this mostly affected the countries in transition. 
Those developments have greatly affected the increase of interest about the concept of organizational performance assessment and performance management. This assessment and overall performance management is showing great interest both to the citizens and other stakeholders, as well as to competition (Brignal et al., 2000). The persistent pressure from public and citizens as well as from the business sector on local governance for an increase of efficiency in service provision leads the governments to engage themselves in strategies and new management methods in order to improve their performance and fulfill the requests from the costumers (citizens, businesses and others) (Sanger, 2008; Demirkaya, 2006).

In some cases professionals argued that generation of qualitative and quantitative data about performance management systems will serve as the baseline for further improvements and enhance the work productivity in any organization (Bouckaert and Dooren, 2002). Another researcher developed a concept that supports the idea that performance is widely linked with the motivation and this is translated in satisfaction of end-user, citizens in this case (Sanger, 2013).

The productivity as result depends on employee motivation and their satisfaction that is directly linked with the employee performance and quality of service delivery (Mkasiwa et al., 2013). It has been widely accepted the statement that performance management systems potentially improve transparency, accountability, increase service quality and increase citizens' satisfaction and citizens' engagement with local governments (Sanger, 2008). Different authors have stated out so far that performance is a multidimensional concept that includes itself and the context surrounding and affecting the performance (Lievens et al., 2016).

Performance in itself shows direct or indirect behavior that is usually in correlation with the quality increase of public services (Lievens et al., 2008). On the other side the context is not directly affecting the outcomes but contribute indirectly and mostly supported from the social-psychological and organizational environment (Sonnentag et al., 2002; 2010). Couple of authors have pointed out that in regards to service quality an increase in the number of conditions and indicators has to be met (Tangen, 2005), including a change in the environment, in organizational culture and in seting up clear goals and objectives within the respective organization (Krasniqi et al., 2015).

Others authors support the idea that performance management system and performance itself heavily depends on skills and motivation (Noe et al., 2011). Thereof it is very important that conditions and indicators for the design of performance development are linked with objectives and purpose in order to monitor the performance improvements and quality increase within the organization (Rantanen et al., 2007). That is why is crucial for all relevant parties including policy makers, researchers and other stakeholders the key performance assessment and performance management indicators to include all relevant aspects of 
organizational performance and to have the capability to address the needs and the concerns from relevant parties within and out of the organization (Williams, 2003).

\section{Methodology}

This research examines the relationship between the performance management and quality improvement of public service delivery in Kosovo. The research is based on the deductive approach and includes different research methods, including the collection and modeling of empirical data and the analysis of data evaluation. In the first stage, large number of empirical literature and articles related to the study topic are analyzed and examined. In the second stage, the primary data are collected through questionnaires and semi-structured interviewed. Within these studies, data from about 900 respondents are collected. After data collection, data preparation and analysis, those are processed and analyzed through SPSS program in order to verify hypothesis raised from the research question.

During recent years, there has been a significant increase and growth on methods and instruments used for the performance management systems in local governance and the impact on quality increase on public service delivery. However, countries in transition are still having deficits and weaknesses, there are still open questions, and problems still need to be addressed and solved. The main research question in this study is:

RQ: How management of performance assessment systems motivates and increases public service quality in the local government in Kosovo?

Based on the above question the research has adopted two hypothesss:

H1: Management of performance assessment system motivates the local government officials.

H2: Motivation of public servants increases public sector quality and citizens' satisfaction.

\section{Data Collection and Data Analysis}

The research examines the relationship between the performance management and quality improvement of public service delivery in Kosovo. The whole research has undergone through two mayor steps. First step incorporates the analysis of secondary data. In the second stage, the questionnaires are prepared and sent to respondents. The questionnaires were designed with characteristics of public service delivery and performance quality. In the next stage, data from 900 respondents through different local governance institutions were collected. The demography of the sample includes $64.44 \%(n=580)$ males and $35.56 \%(n=320)$ females. 
Table 1. Data description for performance assessment management system and performance evaluation on the motivation of staff

\begin{tabular}{|c|c|c|c|c|c|c|c|c|c|}
\hline & \multirow{3}{*}{$\begin{array}{l}\text { Performance } \\
\text { assessment } \\
\text { management } \\
\text { impacts } \\
\text { motivation }\end{array}$} & \multirow[b]{3}{*}{$\mathbf{N}$} & \multirow[b]{3}{*}{ Mean } & \multirow[b]{3}{*}{$\begin{array}{l}\text { Std. } \\
\text { Deviation }\end{array}$} & \multirow[b]{3}{*}{$\begin{array}{l}\text { Std. } \\
\text { Error }\end{array}$} & \multicolumn{2}{|c|}{ 95\% Confidence } & \multirow[b]{3}{*}{ Min } & \multirow[b]{3}{*}{$\operatorname{Max}$} \\
\hline & & & & & & $\begin{array}{l}\text { Interval } \\
\text { Mean }\end{array}$ & & & \\
\hline & & & & & & $\begin{array}{l}\text { Lower } \\
\text { Bound }\end{array}$ & $\begin{array}{l}\text { Upper } \\
\text { Bound }\end{array}$ & & \\
\hline \multirow{6}{*}{$\begin{array}{l}\text { Assessment of } \\
\text { performance } \\
\text { is needed for } \\
\text { informal } \\
\text { evaluation }\end{array}$} & $\begin{array}{l}\text { Totally } \\
\text { disagree }\end{array}$ & 156 & 2.1667 & 1.12142 & .12698 & 1.9138 & 2.4195 & 1.00 & 4.00 \\
\hline & Do not agree & 62 & 2.5806 & 1.20483 & .21639 & 2.1387 & 3.0226 & 2.00 & 5.00 \\
\hline & Not sure & 176 & 3.3636 & .57098 & .06087 & 3.2427 & 3.4846 & 2.00 & 5.00 \\
\hline & Subscribe & 264 & 3.9924 & .15114 & .01315 & 3.9664 & 4.0184 & 3.00 & 5.00 \\
\hline & Totally agree & 242 & 3.2397 & 1.52220 & .13838 & 2.9657 & 3.5137 & 1.00 & 5.00 \\
\hline & Total & 900 & 3.2533 & 1.18371 & .05580 & 3.1437 & 3.3630 & 1.00 & 5.00 \\
\hline \multirow{6}{*}{$\begin{array}{l}\text { Performance } \\
\text { assessment } \\
\text { system } \\
\text { important for } \\
\text { salary } \\
\text { increase }\end{array}$} & $\begin{array}{l}\text { Totally } \\
\text { disagree }\end{array}$ & 156 & 2.5513 & 1.50883 & .17084 & 2.2111 & 2.8915 & 1.00 & 5.00 \\
\hline & Do not agree & 62 & 2.6452 & 1.19857 & .21527 & 2.2055 & 3.0848 & 2.00 & 5.00 \\
\hline & Not sure & 176 & 3.7273 & 1.00261 & .10688 & 3.5148 & 3.9397 & 2.00 & 5.00 \\
\hline & Subscribe & 264 & 3.9697 & 1.59646 & .13895 & 3.6948 & 4.2446 & 1.00 & 5.00 \\
\hline & Totally agree & 242 & 3.8678 & 1.27110 & .11555 & 3.6390 & 4.0966 & 2.00 & 5.00 \\
\hline & Total & 900 & 3.5578 & 1.47360 & .06947 & 3.4213 & 3.6943 & 1.00 & 5.00 \\
\hline \multirow{6}{*}{$\begin{array}{l}\text { Performance } \\
\text { management } \\
\text { and } \\
\text { performance } \\
\text { assessment as } \\
\text { tool for } \\
\text { strategic } \\
\text { planning. }\end{array}$} & $\begin{array}{l}\text { Totally } \\
\text { disagree }\end{array}$ & 156 & 3.0897 & 1.84592 & .20901 & 2.6736 & 3.5059 & 1.00 & 5.00 \\
\hline & Do not agree & 62 & 2.4839 & 1.02862 & .18475 & 2.1066 & 2.8612 & 2.00 & 5.00 \\
\hline & Not sure & 176 & 3.9545 & .90857 & .09685 & 3.7620 & 4.1471 & 3.00 & 5.00 \\
\hline & Subscribe & 264 & 4.6212 & .86959 & .07569 & 4.4715 & 4.7709 & 2.00 & 5.00 \\
\hline & Totally agree & 242 & 3.8430 & 1.32293 & .12027 & 3.6049 & 4.0811 & 2.00 & 5.00 \\
\hline & Total & 900 & 3.8689 & 1.38177 & .06514 & 3.7409 & 3.9969 & 1.00 & 5.00 \\
\hline \multirow{6}{*}{\begin{tabular}{l}
\multicolumn{2}{l}{ Performance } \\
management \\
used for \\
retention or \\
dismissal
\end{tabular}} & $\begin{array}{l}\begin{array}{l}\text { Totally } \\
\text { disagree }\end{array} \\
\end{array}$ & 156 & 2.6667 & 1.62502 & .18400 & 2.3003 & 3.0331 & 1.00 & 5.00 \\
\hline & Do not agree & 62 & 2.7419 & 1.18231 & .21235 & 2.3083 & 3.1756 & 2.00 & 5.00 \\
\hline & Not sure & 176 & 3.6136 & 1.18837 & .12668 & 3.3618 & 3.8654 & 2.00 & 5.00 \\
\hline & Subscribe & 264 & 4.9773 & .26112 & .02273 & 4.9323 & 5.0222 & 2.00 & 5.00 \\
\hline & Totally agree & 242 & 3.7438 & 1.30083 & .11826 & 3.5097 & 3.9779 & 2.00 & 5.00 \\
\hline & Total & 900 & 3.8244 & 1.41668 & .06678 & 3.6932 & 3.9557 & 1.00 & 5.00 \\
\hline \multirow{6}{*}{$\begin{array}{l}\text { Performance } \\
\text { management } \\
\text { system and } \\
\text { performance } \\
\text { assessment as } \\
\text { motivation } \\
\text { tool }\end{array}$} & $\begin{array}{l}\text { Totally } \\
\text { disagree }\end{array}$ & 156 & 2.4744 & 1.77079 & .20050 & 2.0751 & 2.8736 & 1.00 & 5.00 \\
\hline & Do not agree & 62 & 2.7419 & 1.23741 & .22225 & 2.2880 & 3.1958 & 1.00 & 5.00 \\
\hline & Not sure & 176 & 3.0000 & 1.01710 & .10842 & 2.7845 & 3.2155 & 2.00 & 5.00 \\
\hline & Subscribe & 264 & 4.4697 & 1.04436 & .09090 & 4.2899 & 4.6495 & 1.00 & 5.00 \\
\hline & Totally agree & 242 & 3.4298 & 1.63721 & .14884 & 3.1351 & 3.7244 & 1.00 & 5.00 \\
\hline & Total & 900 & 3.4378 & 1.55576 & .07334 & 3.2936 & 3.5819 & 1.00 & 5.00 \\
\hline \multirow{6}{*}{$\begin{array}{l}\text { Performance } \\
\text { management } \\
\text { system is used } \\
\text { for increase } \\
\text { of quality, } \\
\text { efficiency and } \\
\text { accountability }\end{array}$} & $\begin{array}{l}\text { Totally } \\
\text { disagree }\end{array}$ & 156 & 2.3462 & 1.74941 & .19808 & 1.9517 & 2.7406 & 1.00 & 5.00 \\
\hline & Do not agree & 62 & 2.8387 & 1.26746 & .22764 & 2.3738 & 3.3036 & 1.00 & 5.00 \\
\hline & Not sure & 176 & 3.6477 & .93514 & .09969 & 3.4496 & 3.8459 & 3.00 & 5.00 \\
\hline & Subscribe & 264 & 4.7500 & .61003 & .05310 & 4.6450 & 4.8550 & 3.00 & 5.00 \\
\hline & Totally agree & 242 & 4.3967 & 1.34461 & .12224 & 4.1547 & 4.6387 & 1.00 & 5.00 \\
\hline & Total & 900 & 3.8911 & 1.47712 & .06963 & 3.7543 & 4.0280 & 1.00 & 5.00 \\
\hline
\end{tabular}


The group average in Table 1 is 3.414 and the standard deviation is ds $=1.145$. This supports the fact that public sector servants at local government believe that performance management and performance assessment is established as system in organization for different reasons. The analyzed data comparing performance appraisal and performance management system in local governance organization, impacts the motivation above the average of 3.415 .

Table 2. Data description on the role of motivation of public servants toward public service quality increase

\begin{tabular}{|c|c|c|c|c|c|c|c|c|c|}
\hline & \multirow{3}{*}{$\begin{array}{l}\text { Motivation } \\
\text { of public } \\
\text { servants } \\
\text { increase } \\
\text { service } \\
\text { quality }\end{array}$} & \multirow[b]{3}{*}{$\mathrm{N}$} & \multirow[b]{3}{*}{ Mean } & \multirow[b]{3}{*}{ Std. Devi } & \multirow[b]{3}{*}{$\begin{array}{l}\text { Std. } \\
\text { Error }\end{array}$} & \multicolumn{2}{|c|}{ 95\% Confidence } & \multirow[b]{3}{*}{ Min } & \multirow[b]{3}{*}{$\operatorname{Max}$} \\
\hline & & & & & & $\begin{array}{l}\text { Interval } \\
\text { Mean }\end{array}$ & for & & \\
\hline & & & & & & $\begin{array}{l}\text { Lower } \\
\text { Bound }\end{array}$ & $\begin{array}{l}\text { Upper } \\
\text { Bound }\end{array}$ & & \\
\hline \multirow{6}{*}{$\begin{array}{l}\text { Relations } \\
\text { among staff } \\
\text { very good }\end{array}$} & $\begin{array}{l}\text { Totally } \\
\text { disagree }\end{array}$ & 104 & 1.6346 & .74172 & .10286 & 1.4281 & 1.8411 & 1.00 & 3.00 \\
\hline & $\begin{array}{ll}\begin{array}{l}\text { Do } \\
\text { agree }\end{array} & \text { not }\end{array}$ & 108 & 2.4444 & .83929 & .11421 & 2.2154 & 2.6735 & 2.00 & 4.00 \\
\hline & Not sure & 180 & 3.2000 & .76731 & .08088 & 3.0393 & 3.3607 & 2.00 & 4.00 \\
\hline & Subscribe & 274 & 3.9489 & .32812 & .02803 & 3.8935 & 4.0043 & 2.00 & 5.00 \\
\hline & $\begin{array}{l}\text { Totally } \\
\text { agree }\end{array}$ & 234 & 4.5214 & .85700 & .07923 & 4.3644 & 4.6783 & 3.00 & 5.00 \\
\hline & Total & 900 & 3.5000 & 1.17177 & .05524 & 3.3914 & 3.6086 & 1.00 & 5.00 \\
\hline \multirow{6}{*}{$\begin{array}{l}\text { Manager- } \\
\text { employee } \\
\text { relationship } \\
\text { is excellent }\end{array}$} & $\begin{array}{l}\text { Totally } \\
\text { disagree }\end{array}$ & 104 & 1.6346 & .74172 & .10286 & 1.4281 & 1.8411 & 1.00 & 3.00 \\
\hline & $\begin{array}{ll}\begin{array}{l}\text { Do } \\
\text { agree }\end{array} & \text { not }\end{array}$ & 108 & 2.6667 & 1.25893 & .17132 & 2.3230 & 3.0103 & 2.00 & 5.00 \\
\hline & Not sure & 180 & 3.6556 & 1.21008 & .12755 & 3.4021 & 3.9090 & 2.00 & 5.00 \\
\hline & Subscribe & 274 & 4.1095 & 1.53239 & .13092 & 3.8506 & 4.3684 & 1.00 & 5.00 \\
\hline & $\begin{array}{l}\text { Totally } \\
\text { agree }\end{array}$ & 234 & 4.5385 & .84627 & .07824 & 4.3835 & 4.6934 & 3.00 & 5.00 \\
\hline & Total & 900 & 3.6711 & 1.51409 & .07138 & 3.5308 & 3.8114 & 1.00 & 5.00 \\
\hline \multirow[t]{6}{*}{$\begin{array}{l}\text { Payment } \\
\text { suitable }\end{array}$} & $\begin{array}{l}\text { Totally } \\
\text { disagree }\end{array}$ & 104 & 1.6923 & .80534 & .11168 & 1.4681 & 1.9165 & 1.00 & 4.00 \\
\hline & $\begin{array}{ll}\begin{array}{l}\text { Do } \\
\text { agree }\end{array} & \text { not }\end{array}$ & 108 & 2.4815 & .88469 & .12039 & 2.2400 & 2.7230 & 2.00 & 5.00 \\
\hline & Not sure & 180 & 3.6556 & 1.21008 & .12755 & 3.4021 & 3.9090 & 2.00 & 5.00 \\
\hline & Subscribe & 274 & 4.7591 & .70216 & .05999 & 4.6405 & 4.8778 & 2.00 & 5.00 \\
\hline & $\begin{array}{l}\text { Totally } \\
\text { agree }\end{array}$ & 234 & 4.3846 & .92705 & .08571 & 4.2149 & 4.5544 & 3.00 & 5.00 \\
\hline & Total & 900 & 3.8133 & 1.38744 & .06540 & 3.6848 & 3.9419 & 1.00 & 5.00 \\
\hline \multirow{4}{*}{$\begin{array}{l}\text { Staff } \\
\text { development } \\
\text { and staff } \\
\text { support is in } \\
\text { place }\end{array}$} & $\begin{array}{l}\text { Totally } \\
\text { disagree }\end{array}$ & 104 & 1.8654 & .99072 & .13739 & 1.5896 & 2.1412 & 1.00 & 3.00 \\
\hline & $\begin{array}{ll}\begin{array}{l}\text { Do } \\
\text { agree }\end{array} & \text { not } \\
\end{array}$ & 108 & 2.8333 & 1.24005 & .16875 & 2.4949 & 3.1718 & 2.00 & 5.00 \\
\hline & Not sure & 180 & 3.4556 & 1.39953 & .14752 & 3.1624 & 3.7487 & 2.00 & 5.00 \\
\hline & Subscribe & 274 & 4.8686 & 61617 & .05264 & 4.7645 & 4.9727 & 2.00 & 5.00 \\
\hline
\end{tabular}


Management and Assessment of Human Performance Toward Service Quality: The Case of Kosovo's Public Sector

234

\begin{tabular}{|c|c|c|c|c|c|c|c|c|c|}
\hline & $\begin{array}{l}\text { Totally } \\
\text { agree }\end{array}$ & 234 & 4.2137 & .98111 & .09070 & 4.0340 & 4.3933 & 3.00 & 5.00 \\
\hline & Total & 900 & 3.8244 & 1.41668 & .06678 & 3.6932 & 3.9557 & 1.00 & 5.00 \\
\hline \multirow{6}{*}{$\begin{array}{l}\text { There is } \\
\text { career } \\
\text { advancement } \\
\text { and } \\
\text { promotion }\end{array}$} & $\begin{array}{l}\text { Totally } \\
\text { disagree }\end{array}$ & 104 & 1.3654 & .81719 & .11332 & 1.1379 & 1.5929 & 1.00 & 4.00 \\
\hline & $\begin{array}{ll}\text { Do } & \text { not } \\
\text { agree }\end{array}$ & 108 & 2.5926 & 1.00035 & .13613 & 2.3195 & 2.8656 & 1.00 & 5.00 \\
\hline & Not sure & 180 & 2.7000 & .77096 & .08127 & 2.5385 & 2.8615 & 1.00 & 5.00 \\
\hline & Subscribe & 274 & 4.8905 & .52411 & .04478 & 4.8020 & 4.9791 & 2.00 & 5.00 \\
\hline & $\begin{array}{l}\text { Totally } \\
\text { agree }\end{array}$ & 234 & 4.6923 & .72471 & .06700 & 4.5596 & 4.8250 & 3.00 & 5.00 \\
\hline & Total & 900 & 3.7178 & 1.48276 & .06990 & 3.5804 & 3.8551 & 1.00 & 5.00 \\
\hline \multirow{6}{*}{$\begin{array}{l}\text { Flexible } \\
\text { time } \\
\text { schedule and } \\
\text { work-life } \\
\text { balance in } \\
\text { place }\end{array}$} & $\begin{array}{l}\text { Totally } \\
\text { disagree }\end{array}$ & 104 & 1.6154 & 1.40243 & .19448 & 1.2249 & 2.0058 & 1.00 & 5.00 \\
\hline & $\begin{array}{ll}\text { Do } & \text { not } \\
\text { agree } & \end{array}$ & 108 & 2.5556 & .71814 & .09773 & 2.3595 & 2.7516 & 1.00 & 4.00 \\
\hline & Not sure & 180 & 2.5556 & 1.14275 & .12046 & 2.3162 & 2.7949 & 1.00 & 5.00 \\
\hline & Subscribe & 274 & 4.9124 & .46137 & .03942 & 4.8345 & 4.9904 & 1.00 & 5.00 \\
\hline & $\begin{array}{l}\text { Totally } \\
\text { agree }\end{array}$ & 234 & 4.9829 & .18490 & .01709 & 4.9490 & 5.0168 & 3.00 & 5.00 \\
\hline & Total & 900 & 3.7956 & 1.55177 & .07315 & 3.6518 & 3.9393 & 1.00 & 5.00 \\
\hline \multirow{6}{*}{$\begin{array}{l}\text { Organization } \\
\text { is human } \\
\text { responsible } \\
\text { oriented }\end{array}$} & $\begin{array}{l}\text { Totally } \\
\text { disagree }\end{array}$ & 104 & 1.3654 & .81719 & .11332 & 1.1379 & 1.5929 & 1.00 & 4.00 \\
\hline & $\begin{array}{ll}\text { Do } & \text { not } \\
\text { agree } & \\
\end{array}$ & 108 & 2.1111 & .88310 & .12018 & 1.8701 & 2.3522 & 1.00 & 4.00 \\
\hline & Not sure & 180 & 3.0444 & .49517 & .05220 & 2.9407 & 3.1482 & 2.00 & 4.00 \\
\hline & Subscribe & 274 & 3.9416 & .31545 & .02695 & 3.8883 & 3.9949 & 2.00 & 4.00 \\
\hline & $\begin{array}{l}\text { Totally } \\
\text { agree }\end{array}$ & 234 & 4.9658 & .26036 & .02407 & 4.9181 & 5.0135 & 3.00 & 5.00 \\
\hline & Total & 900 & 3.5111 & 1.29797 & .06119 & 3.3909 & 3.6314 & 1.00 & 5.00 \\
\hline \multirow{6}{*}{$\begin{array}{l}\text { working } \\
\text { conditions } \\
\text { and } \\
\text { environment } \\
\text { are at } \\
\text { suitable } \\
\text { level }\end{array}$} & $\begin{array}{l}\text { Totally } \\
\text { disagree }\end{array}$ & 104 & 1.5000 & 1.17990 & .16362 & 1.1715 & 1.8285 & 1.00 & 5.00 \\
\hline & $\begin{array}{ll}\text { Do not } \\
\text { agree }\end{array}$ & 108 & 1.9630 & .19063 & .02594 & 1.9109 & 2.0150 & 1.00 & 2.00 \\
\hline & Not sure & 180 & 3.1444 & .41220 & .04345 & 3.0581 & 3.2308 & 2.00 & 4.00 \\
\hline & Subscribe & 274 & 3.9562 & .20539 & .01755 & 3.9215 & 3.9909 & 3.00 & 4.00 \\
\hline & $\begin{array}{l}\text { Totally } \\
\text { agree }\end{array}$ & 234 & 4.9829 & .18490 & .01709 & 4.9490 & 5.0168 & 3.00 & 5.00 \\
\hline & Total & 900 & 3.5378 & 1.27496 & .06010 & 3.4197 & 3.6559 & 1.00 & 5.00 \\
\hline
\end{tabular}

Based on the Table above the group average is 4.09 and the standard deviation is ds $=0.76$. According to this study and the framework adopted, the variables of performance are contested and still open for debates.

Thereof the study has developed the approach of correlation analysis among specific figures and variables. In this case, the results show that motivation of employees will increase productivity and quality of services. 


\subsection{Confirmation of Hypotheses}

Table 3 reflects the fact that assessment of performance system and evaluation influences motivation in public service delivery which is supported by $58 \%$ of the respondents. Assessment of performance system and evaluation is an independent variable and the motivation is the dependent variable. This fact supports the first hypothesis so paper concludes that first hypothesis has been verified.

Table 3. Correlation between performance assessment management system and performance evaluation with the motivation of staff

\begin{tabular}{cccc}
\hline & $\begin{array}{c}\text { Assessment of } \\
\text { performance is } \\
\text { needed for informal } \\
\text { evaluation }\end{array}$ & $\begin{array}{c}\text { Assessment of performance } \\
\text { system and evaluation impacts } \\
\text { motivation in public service } \\
\text { delivery }\end{array}$ \\
\hline $\begin{array}{c}\text { Assessment } \begin{array}{c}\text { of } \\
\text { performance }\end{array} \\
\text { is needed for } \\
\text { informal } \\
\text { evaluation }\end{array}$ & $\begin{array}{c}\text { Pearson } \\
\text { Correlation }\end{array}$ & 1 & $.582^{* *}$ \\
\cline { 2 - 4 } & $\mathrm{N}$ & 900 & .001 \\
\hline
\end{tabular}

Based on correlation coefficients from Table 4 the research assesses that motivation affects directly the increase in public service quality and in productivity. This correlation coefficient is supported by $80 \%$ of the respondents, and as result, the second hypothesis is verified. In this case, motivation is an independent variable and the dependent variable is the service quality increase and the increase in productivity.

Table 4. Correlation between motivations of public servants with public sector quality increase

\begin{tabular}{c|c|c|c}
\multicolumn{2}{c|}{} & Motivation & $\begin{array}{c}\text { Motivation of public servants directly } \\
\text { affects public service quality increase }\end{array}$ \\
\hline \multirow{3}{*}{ Motivation } & Pearson Correlation & 1 & $.802^{* *}$ \\
\cline { 2 - 4 } & Sig. (2-tailed) & & .000 \\
\cline { 2 - 4 } & $\mathrm{N}$ & 450 & 450 \\
\hline
\end{tabular}

\section{Conclusions and Recommendations}

Having analyzed data from different sources and compared with primary data collected and knowing that all local government assessment frameworks are usually normative based and value oriented, the paper concludes that the performance management and performance assessment directly supports the employee's motivation. Based on this correlation it derives that the most important factor for motivation in our case study is salary increase that serves as the strongest stimulus for the staff motivation. This is understandable having analyzed the overall picture 
of the country and the level of unemployment. The analysis and statistics enable and validate the broader concept of performance measurement in the local context including other dimensions beside motivation through salary and work security.

Other important dimensions of public service performance measurement include dimensions related to the mobilization means including mastering of deployment from human resources through optimization and effectiveness, financial resources through compliance and spending economy as well as organizational resources with all its aspects including culture, structure and cognitive fostering.

Thereof considering the findings and impact on motivation, the conducted research recommends to the local government authorities broader engagement and modern management approaches, new methods of performance assessment and evaluation in order to increase the motivation among employees and directly increase the quality of services and productivity.

\section{References:}

Afful-Broni, A. 2012. Relationship between motivation and job performance at the University of Mines and Technology, Tarkwa, Ghana. Leadership Lessons, Vol. 3, No. 3, 309-314.

Atkinson, A.A. and McCrindell, J.Q. 1997. Strategic performance measurement in government. CMA Magazine, 20-23.

Bouckaert, G. \& Dooren, W.V. 2002. Performance measurement: Getting results. Public Performance \& Management Review, 25(3), 329-335.

Brignall, S., Modell, S. 2000. An Institutional perspective on performance measurement and management in the " new public sector". Management Accounting Research, 11, 281-290.

Christensen, T., Laegreid, P., Roness, G.P., Rovik, A.K. 2007. Organization theory and the public sector: Instrument, culture and myth. London, Taylor \& Francis Group.

Hood, C. 1995. The "New Public Management" in the 1980s: Variations on a Theme. Accounting, Organizations and Society, 20, 93-109.

Krasniqi, I., Ismajli, N., Zeqiri, J. \& Qosja, E. 2015. The Importance of Motivation Factors on Employee Performance in Kosovo Municipalities. Journal of Public Administration and Governance, 5, 10.5296/jpag.v5i1.7082.

Levens, F., Conway, J.M., Corte, W.D. 2008. The relative importance of task, citizenship and counter productive performance to job performance ratings: Do rater source and team-based culture matter? Journal of Occupational and Organizational Psychology, The British Psychological Society, 2.

Levens, F. \& Slaughter, J. 2016. Employer Image and Employer Branding: What we Know and What we Need to Know. Annual Review of Organizational Psychology and Organizational Behavior, 3, 10.1146/annurev-orgpsych-041015-062501.

Mkasiwa, T.A., Gasper, A.F. 2012. Complexities in Performance Measurement and the Reaction of Actors: The Case of Tanzania. Journal of Finance and Accounting, 2(3), 41-50, doi: 10.12691/jfa-2-3-1.

Noe, R.A., Hollenbeck, J.R., Wright, P.M. 2011. Fundamental of Human Resource Management. Published by McGraw-Hill/Irwin, Inc. 
Rantanen, H., Kulmala, H., Lonnqvist, A., Kujansivu, P. 2007. Performance measurement systems in the Finnish public sector. International Journal of Public Sector Management, 20(5), 415-433.

Sanger, M.B. 2008. From measurement to management: Breaking through the barriers to state and local performance. Public Administration Review, 68(Special Issue), S70S85.

Sanger, M.B. 2013. Does measuring performance lead to better performance? Journal of Policy Analysis and Management, 32(1), 185-203.

Sonnentag, S. \& Frese, M. 2005. Performance Concepts and Performance Theory. 10.1002/0470013419.ch1.

Sonnentag, S., Frese, M. 2002. Psychological management of individual performance. John Wiley \& Sons, Ltd.

Sonnentag, S., Volmer, J., Spychala, A. 2010. Job Performance. Handbook of organization behavior, vol. 1, 428-435.

Tangen, S. 2005. Demystifying productivity and performance. International Journal of Productivity and Performance Management, 54(1), 34-46, https://doi.org/10.1108/17410400510571437.

Walker, R.M., Boyne, A.G. and Brewer, A.G. (Eds). 2010. Public management and performance: Research directions. Cambridge, Cambridge University Press.

Williams, D.W. 2003. Measuring government in the early twentieth century. Public Administration Review, 63(6), 643-659.

World Economic Forum. 2013. The global competitiveness report (2013-2014). Retrieved from World Economic website, http://www3. weforum.org/docs/WEF_Global Competitiveness Report_2013-2014.pdf. 